\title{
The Extraordinary Case of the Boole Family
}

\section{Moira Chas}

\section{Introduction}

George Boole (1815-1864) was a professor of mathematics at the University of Cork when he married Mary Everest (1832-1916). Mary studied and wrote incessantly about many topics, including mathematics education. The middle of their five daughters, Alicia (1860-1940) (who was only four years old when her father died) made discoveries about four-dimensional Euclidean geometry. George Boole's ideas impacted various areas of mathematics, most notably logic, where they became the foundation of the structures that underlie today's computer technology. He is among the select group of mathematicians from whose surname an oftused adjective derives. Many of the facts mentioned in this article were found by performing Boolean searches on the Internet, illustrating the wide use of the adjective Boolean.

The main purpose of this article is to discuss the life and mathematical ideas of George Boole, Mary Everest Boole, and Alicia Boole Stott.

Charles Hinton, a friend (and later member by marriage) of the Boole family, taught Alicia basic ideas about the four-dimensional cube-or tesseract, as he had named it. A few years later Alicia edited a book he had written about these ideas. In this article it is conjectured that her work on the appendix of Hinton's book was what motivated her study of regular four-dimensional analogues of the Platonic solids.

The remarkable life and intellectual production of other members of the Boole family will also be briefly discussed.

Moira Chas is an associate professor of mathematics at Stony Brook University. Her email address is moira.chas@stonybrook.edu. The author was partially supported by NSF grant 1509280.

For permission to reprint this article, please contact: reprint-permission @ams.org.

DOI: https://dx.doi.org/10.1090/noti 1996

\section{George Boole on the Track of Knowledge}

George Boole was born in 1815, in Lincoln, England, into the family of a shoemaker with an original mind and a burning thirst for knowledge. Signs of George's exceptional and diverse talents surfaced in his early childhood. Because his family's economic situation was always precarious, he only received a very basic and brief formal education, but for his informal education, not even the sky was the limit. He studied English and elementary mathematics with his father and read every book that fell into his hands: history, biography, science, poetry, novels. Friends and public libraries were the main sources of material.

Someone guided him on his first steps in Latin. He continued studying alone until he mastered Greek, French, German, and Italian. This language ability would later allow Boole to be au courant of mathematical developments in Europe. It also prompted him to reflect on the structure of sentences and arguments, reflections that would impact his ideas on logic. Like Ada Lovelace, Madame du Châtelet, and Maria Agnesi, he used his knowledge of languages to further his mathematical and philosophical understanding.

\section{Focused on Mathematics}

George's father devoted too much of his energy to building optical instruments and not enough to making shoes; this tendency turned out to be devastating for the Boole family's finances. The family business collapsed when George was sixteen years old, compelling him to start working as an assistant teacher to support his parents and siblings. About the same time, George's vigorous intellectual efforts focused on mathematics. He read and mastered (in the original French version) Differential and Integral Calculus by Silvestre Lacroix. When asked how he managed to comprehend such a difficult book, he answered that he did not stop reading and rereading until he understood. This, while fully supporting his family and working on projects for the community. 


\section{HISTORY}

A letter he wrote to a friend when he was nineteen years old reveals the germs of ideas related to logic: "...we are permitted to employ symbols to represent whatever we choose that they should represent-things, operations, relations, etc., provided 1st, that we adhere to the signification once fixed, 2nd, that we employ the symbols in subjection to the laws of the things for which they stand."

Boole was not twenty years old when he founded his own school; he would work there until 1849, when he was appointed professor of mathematics at Queens College, Cork, Ireland.

\section{First Mathematical Papers}

In 1839 Duncan F. Gregory, the editor of the Cambridge Mathematical Journal, received a scientific paper submitted by George Boole. This first submission was the start of a friendly and stimulating correspondence which continued until Gregory's untimely death in 1844. The men were close in age, but Gregory had greater academic experience; he was able to help Boole put his first texts in a more standard form. The Cambridge Mathematical Journal would publish more than twenty of Boole's papers on a diverse array of topics, including differential equations, logic, probability, linear transformations, integration, and geometry.

One of Boole's works published by Gregory, "Exposition of a general theory of linear transformations" [2], was the seed of what later became an important topic: invariant theory [15, p. 54]. The general quadratic form $x^{2}+b x y+$ $c y^{2}$ has $b^{2}-4 a c$ as its discriminant. Boole was the first to formulate and describe geometrically the statement that after a linear change of variables the discriminant of the new form is equal to the discriminant of the original form multiplied by the square of the determinant of the change of variables.

Boole's observation was soon picked up by Arthur Cayley, who generalized it to forms of higher degree in two or more variables. The algebraic theory of invariants that followed is a subject that is still of interest today, as illustrated by the widely used work Geometric Invariant Theory by David Mumford, published in 1965. Boole and Cayley became friends and frequent correspondents.

Boole also corresponded with the mathematician $\mathrm{Au}-$ gustus De Morgan, with whom he shared an interest in many topics, including mathematical logic, the writing of mathematical textbooks, astronomy, and the education of the working classes.

In 1843 Boole, still a schoolmaster managing his Boarding School for Young Gentlemen, finished a paper on differential equations, "On a general method of analysis" [3, p. 119], where he combined an exponential substitution and a variation of parameters with the method of separation of symbols. (The method was called separation of symbols because it abstracted the symbol $d / d x$ from the symbol $d y / d x$.) Boole writes, "The position which

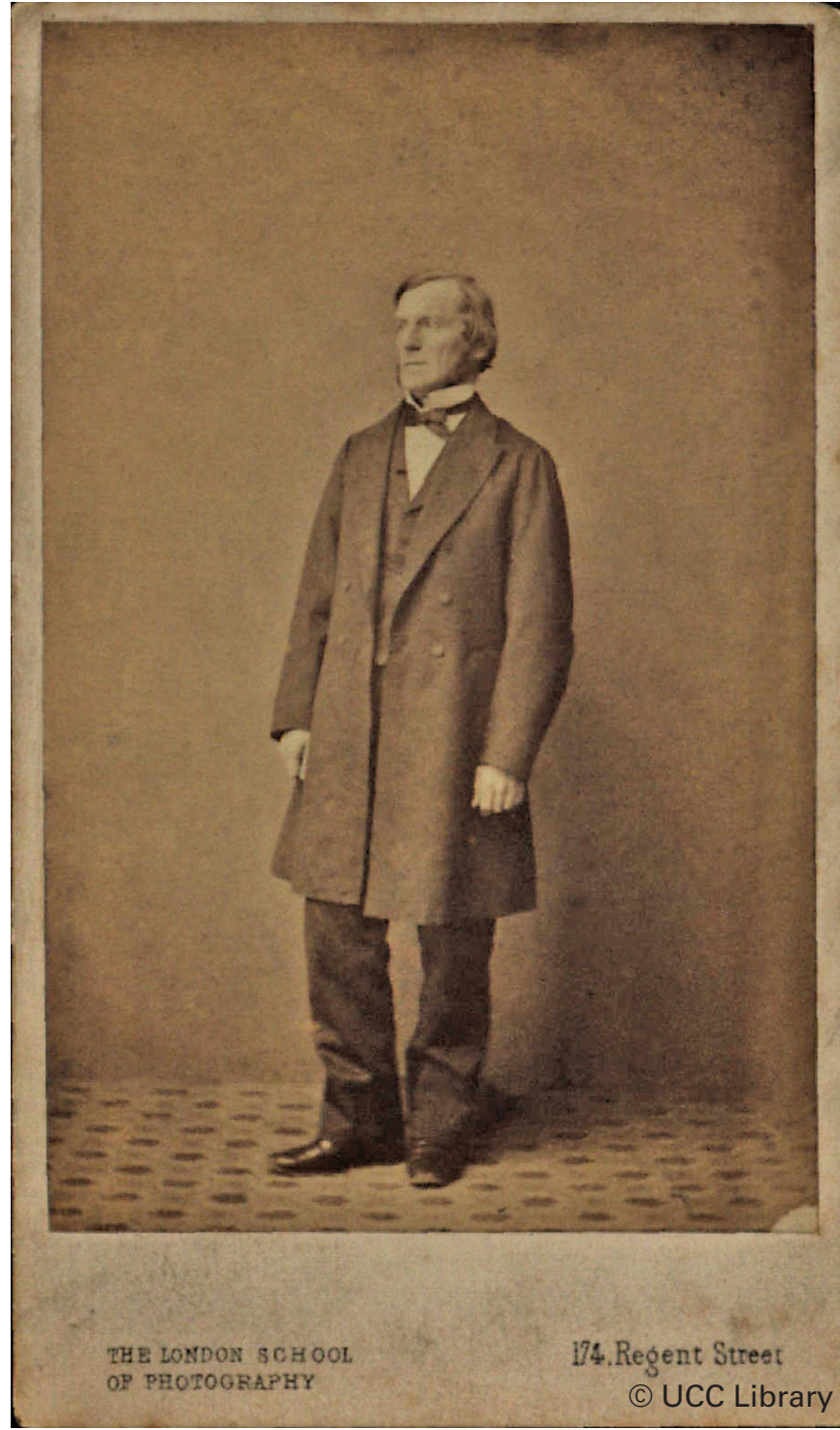

Figure 1. BP/1/356 Mounted monochrome full-length portrait of Boole from The London School of Photography, 174 Regent Street, London.

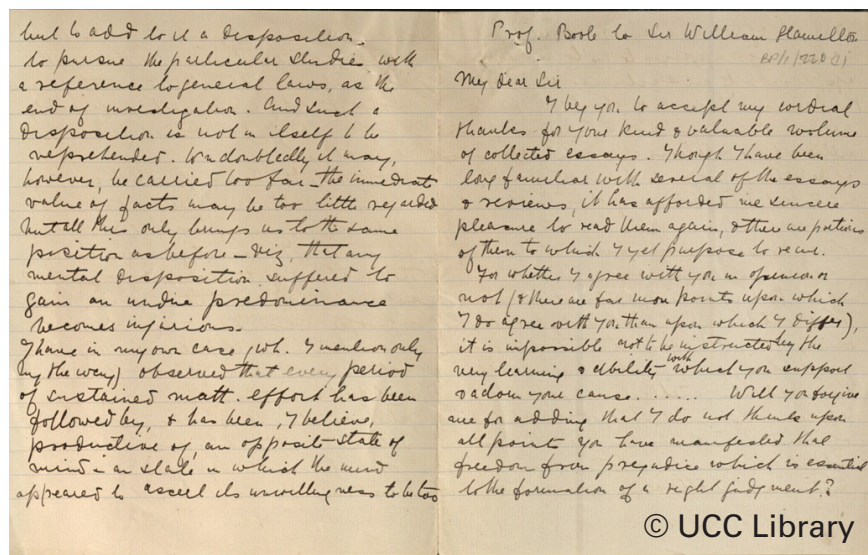

Figure 2. BP/1/220 Letter from George Boole to Sir William Hamilton (1852). 
I am most anxious to establish is that any great advance in the higher analysis must be sought for in an increased attention to the laws of the combination of symbols" [3, p. 282]. This work contains possibly the first clear definition of operator and has the germ of an idea that will recur in Boole's work: an operator, D (for differentiation), is a mathematical object, and so, for instance, polynomials in D can be used as a tool to solve differential equations-an adumbration of the modern theory of differential algebra and "D-modules."

"On a general method of analysis" was too long to be published in the Cambridge Mathematical Journal. Following Gregory and De Morgan's advice, Boole dared to submit it to the Royal Society for publication in their prestigious Philosophical Transactions.

MacHale writes that although there is no definite proof, it is likely that Boole's paper was very close to being rejected without even being read [15, p. 61]. In any case, intellectual reason prevailed and the paper was sent to two referees. One of them rejected it. The other one was Phillip Kelland, professor of mathematics at the University of Edinburgh, who would write a few years later, "The Royal Society did me the honour to refer the paper to me, and I had the good fortune at once to perceive its importance, and to recommend the Society to bestow on it a mark of approbation" [15, p. 62].

The article of the unknown small town schoolmaster was eventually awarded the gold medal of the Royal Society for being the best paper.

\section{Focused on Logic}

During 1847 the echoes of a bitter controversy between De Morgan and the Scottish logician William Hamilton (whose name is almost identical to that of the Irish creator of quaternions) prompted Boole to revisit his past thoughts about the definition of a structure composed of symbols and of laws about how to operate with those symbols. His work on the topic culminated in the publication of two books: The Mathematical Analysis of Logic, Being an Essay towards a Calculus of Deductive Reasoning [4] in 1847 and An Investigation of the Laws of Thought [5] in 1854. As the titles suggest, and as he declared in [5, p. 1], his goal was "to investigate the fundamental laws of those operations of the mind by which reasoning is performed; to give expression to them in the symbolic language of a Calculus, and upon this foundation to establish the science of Logic and construct its method." But he made the crucial observation that these structures are susceptible to other interpretations. Indeed, in the second book, he proposed an interpretation of his calculus of logic for the theory of probability.

Boole did not define Boolean algebras as we know them today, but his vision inspired the mathematical engineer Claude Shannon in 1939 to use these structures as models of digital switching circuits [17]. The consequences of these analyses underlie all of today's computer technology.

\section{Professor Boole, Finally}

After fifteen years of tireless work, Boole, still a full-time schoolmaster, had a scholarly production comparable in quantity to that of many professors of mathematics of his time. One of his articles had won the Royal Society's gold medal, and his knowledge of arts and sciences was broader and deeper than that of most, if not all, holders of university diplomas. Although he had considered attending college more than once, his family's economic dependence on him did not allow it. On the other hand, it is entirely possible that this lack of formal training, together with his exceptional mind and work ethic, could account in part for the deep originality of his work.

In 1846 Boole applied for the position of professor of mathematics at the newly opened Queen's College in Cork. He presented testimonials (that is, recommendation letters) from some of the leading mathematicians of Great Britain-Arthur Cayley, Augustus De Morgan, Phillip Kelland, William Thomson (later Lord Kelvin), and Charles Graves-as well as letters from a student and various citizens of Lincoln. Thomson's comment summarizes the sentiment: "His appointment to such a situation would be highly desirable for the sake of Science, to which a devoted cultivator would thus be secured" [15, p. 79].

Three years went by with no word from the authorities about the appointment. At some point, he even requested that his nomination be withdrawn, only to subsequently retract his request and keep waiting. Finally, the desired answer arrived, and Boole set out to Cork to take charge of his new duties.

Before his departure, the members of the Mechanics' Institute, an establishment that provided adult education and where Boole had generously volunteered, raised a subscription to buy him a present. When he learned of this project, Boole insisted that the money be used to buy books for the library or a telescope for the institute, but in vain. The members' appreciation was embodied in the Atlas of Physical Geography they presented to Boole.

\section{Mary, the Lover of Algebra}

In 1850 a young woman named Mary Everest visited her uncle, John Ryall, vice principal and professor of Greek at Queen's College in Cork. A frequent guest of the house was another professor at the college, George Boole. Very soon they discovered their common passion for mathematics, and George agreed to tutor Mary in person and by correspondence.

Mary was unlike any woman George had ever met. She had a mind of her own and had spent most years of her life putting it to work. Having spent a large portion of her childhood in France, she was bilingual (although she thought 
in French). Her father was ill and had moved the family to be near Samuel Hahnemann, the founder of homeopathy. Hahnemann had prescribed a draconian regime for Mary's father, followed also by his family and their servants. This regime, Mary wrote, included ice cold baths, vigorous walks before breakfast, and a strict diet [11, p. 1507].

A fundamental influence in Mary's childhood was her French tutor, Monsieur Deplace (first name lost in time), who appreciated and stimulated her singular mind. His teaching method made an indelible impression on her: M. Deplace would guide her train of thought with small questions, whose answers she would write down, until the solution of the problem she was looking for was in front of her eyes, and she realized it was she who had found it [11, p. 1515].

Algebra was among her favorite subjects. She once wrote, "I have often told myself that I know nothing about God except that he made Algebra, which I have always felt was quite sufficient reason for loving him with all my heart and soul, and doing, so far as I could, whatever I thought he wished. As for his loving, that was obvious to me always. He made me capable of understanding Algebra. I have always known that even Omnipotence could not have done that except by great love for me" [11, p. 1523].

This girl for whom algebra was reason enough to love God overheard her father regretting that she was a woman, given her interest and talent for mathematics. Had she been a man, Cambridge would have been her natural place. In Cambridge, "the home of Mathematics," she would have found "a glorious being living there whose name was Babbage, and who was the King or High Priest of Mathematics" [11, p. 1521]. This was a painful awakening: the doors of that wonderful place where people discussed math all day long were closed to women [11, p. 1521].

Mary and George corresponded for five years, developing a deep friendship that went beyond the discussion of science. She writes that on one occasion he visited her family to teach her and other youngsters mathematics "not as a lesson, but as a matter of interest" [11, p. 19]. Besides teaching mathematics, he would read Milton to them, and "discovered queer old books on the shelves that no one else ever looked at." Mary added, "He was interested in so many things and so reverent over the smallest, that he puzzled us all a good deal." It is likely that George thought of marrying her, but he saw the eighteen years of difference between them as an insurmountable obstacle. Moreover, his health was not optimal (nor was hers) and his salary was small. These were the opinions voiced by George's friends [15, p. 108]. Nevertheless, he proposed to Mary after her father's death, and they were married in 1855 .

Mary describes their nine years together as a "sunny dream" [11, p. 21]. Those pages show how she admires George's genius without reserve and her appreciation for his unique character: "Some friends refer to him as a saint,"
Mary writes, "but he struggled. He hated pretension and selfishness but never was uncharitable to selfish or conceited people; he loved meditation but was rarely idle; he loved seeing others cheerful and dreaded giving pain, but he was always truthful." She recalls a description of George she once heard: "He is like-the sort of man to trust your daughter with." He was always ready to have an interesting conversation if there was an appropriate interlocutor: Once he told Mary that he had "gone into a shop and found the mind behind the counter intelligent, so he had asked him to come and have some more talk about optics" [11, p. 31].

A sequence of five babies, five daughters, came into the Boole's house in rapid succession. Mary Ellen, Margaret, Alicia, Lucy, and Ethel. George was a loving and unusual father: he never used baby language with them. Instead, he would kindly teach them how to pronounce words; he gave a great deal of thought to their acquisition of languages. He also had them help the servants in housework to teach them not to be selfish. Family peace was crucial for George, who studied the problem of domestic relations with the same intensity he put into the understanding of mathematics.

During their brief courtship, George had promised Mary that she would be able to help him in his research. For a few years they could not find how to proceed, until a publisher told her, "Why do you want to help your husband to make discoveries? He is perfectly well able to do that without you. The thing he can't do is to bring down his discoveries to the level of those who want to understand them; suppose you try to help him make himself intelligible" [11, p. 28]. The suggestion was successfully implemented: A Treatise on Differential Equations [6], informally edited by Mary, was published in 1859. To help in the preparation, George suggested that Mary attend his lectures to the senior class, and she did so for a few weeks. In those days, higher education for women was unthinkable. This was communicated to Mary, who, to save trouble, desisted. The senior class decided then to move the lectures to the Booles' residence [11, p. 29].

The purpose of this book, he explains in the introduction, is "to convey an account of the present state of knowledge on the subject of Differential Equations, as was consistent with the idea of a work intended, primarily, for elementary instruction. It was my object, first of all, to meet the wants of those who had no previous acquaintance with the subject, but I also desired not quite to disappoint others who might seek for more advanced information" [6, p. iii].

The text was adopted by Cambridge University, and its use spread through the decades to come. A year later Boole published A Treatise on the Calculus of Finite Differences [7], again with Mary as informal editor. This second textbook was very well received by the mathematical community, and it is still considered a classic in the field of finite differences. In fact, Boole was better known for these two books than for his work in logic [15, p. 222]. 


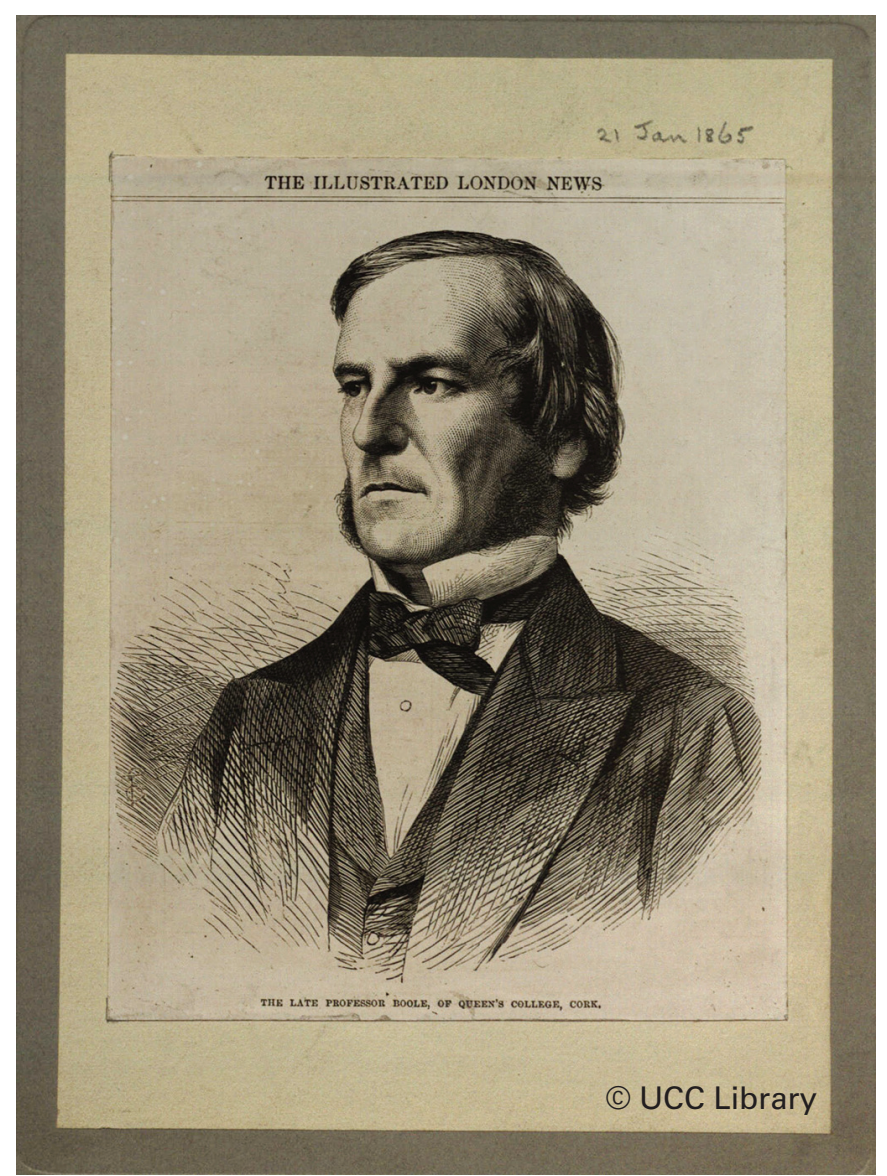

Figure 3. BP/1/352 Photograph of an illustration of Boole taken from The Illustrated London News, 21 Jan. 1865.

\section{An Abrupt End for the Sunny Dream}

George had always worked long and intense hours. The administrative duties of his job were not small, and his teaching load was quite heavy (he had more students in his charge than any other professor). His health, never strong, deteriorated during 1864. One rainy day in November he walked the three miles from his house to the university. Always striving to perform his duties, he gave what would be his last lecture in wet clothes. Soon after, he showed a fever and other symptoms of illness that forced him to lie in bed. A letter of a friend of the Booles describes Mary's anguish as she saw George's health inexorably worsening despite all her efforts in following the instructions of the doctor that he had requested [15, p. 240].

During George's illness, Mary would bring him their youngest daughter, Ethel, for a daily visit. On the eighth of December he requested to see the baby for a second time. "Meine Engelchen, sie ist eine Erscheinung" (My little angel; she is a vision), he exclaimed in German. He died not long after uttering those words [11, p. 47].

\section{Mary Spreads HerWings in London}

George's untimely death changed his loving young wife into a penniless widow, responsible for five daughters ranging from eight years old to six months. The small pension that De Morgan and other friends managed to obtain for her was not sufficient, and Mary was forced to move to London and take a job.

About her new job, Mary would write, "In 1865 I entered, as Librarian, Queen's College, Harley Street, the first Ladies' College opened in England. At that time Cambridge and Oxford gave no degrees either to Jews or to women. Queen's College had no degrees to confer; it was merely educational. The pupils were all women; the professors were all men; women were admitted on the teaching staff only as subordinate assistants" [11, p. 1091]. There are many indications that Mary was prepared for teaching and would have loved to do it, but once again her gender was an obstacle. Instead, she tutored young children in mathematics and organized regular meetings with the students under the title Symbolical Methods of Study. A diverse selection

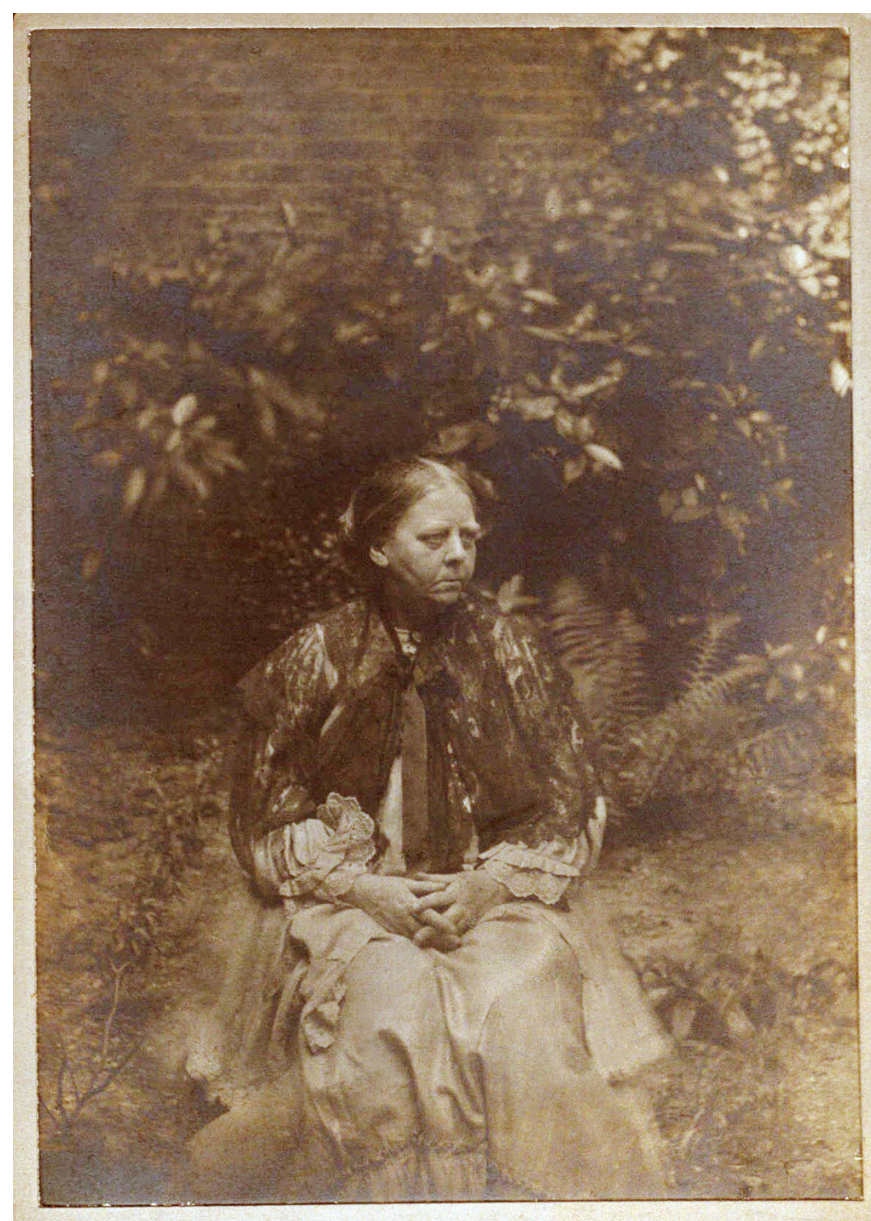

(C) UCC Library

Figure 4. BP/1/361 Monochrome photograph of Mary Boole seated outdoors in a garden. 
of topics was discussed, including the mathematical work of George Boole and Charles Babbage. Mary applied her pedagogical ideas to these meetings. Years afterward, a student would write, "I thought we were being amused, not taught. But after I left College I found you had given us a power. We can think for ourselves, and find out what we want to know" [11, p. 478].

The minutes of the Council of Queen's College record that she took a leave of absence in 1874 due to illness; in the following year "her illness had assumed the form of temporary derangement," and she resigned from her position [1, p. 18].

Now Mary was in her fifties, at a moment and place where the public life of women was supposed to end. Instead, she started giving lectures and writing articles and books at a surprising pace. Despite increasing health problems, she barely reduced the intensity of her intellectual activity until her death at eighty-four. Her persistence reminds one of George's, in the sense that both perceived obstacles not as insurmountable, but just as something to deal with.

Mary defined herself as a mathematical psychologist (see, for instance, the dedication of [11, p. 693]) and was at her best when writing about this area. She pondered the process of learning mathematics and the roles of the conscious and the unconscious mind. Many of her ideas are standard now but were considered eccentric or absurd in her day and had to be independently rediscovered [16].
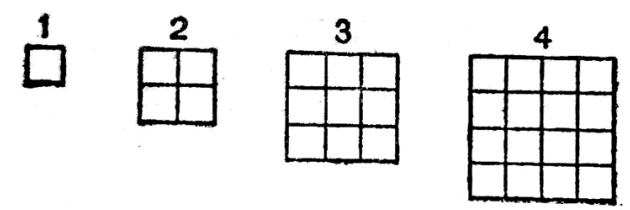

\section{$A$}

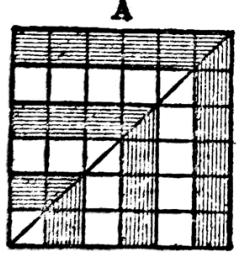

6

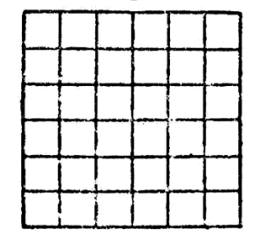

5

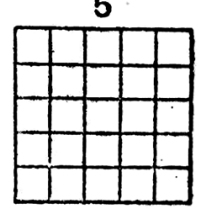

Figure 5. Figure from Mary's book discussing teaching formulae related to $(n+1)^{2}$.

She explained, for instance, that a child should discover a formula such as $(n+1)^{2}=n^{2}+2 n+1$ by computing a sequence of examples and by drawing or building shapes like those in Figure 5. Mary insisted, echoing her former tutor, M. Deplace, that "no explanation should be attempted" [11, p. 873].

She reclaimed the value of geometric imagination and the use of what are now called manipulatives: "From the time when an infant begins to stroke the cat, to smell flowers, and to handle a spoon, have geometric solids as ornaments or toys, so that the senses of sight and touch may actually develop in contact with true type-form" [11, p. 905]. "Lastly, -and this is probably the most important preparation for future living comprehension of mathematical ideas - there is the cultivation of the geometric imagination. At the same age at which a child begins to realize that a tadpole grows into a frog, a boy into a man, a seedling into a flowering plant, let him have the opportunity of watching also how one geometrical type-form grows out of, or flows into, another. A common night-light placed in the bottom of a deep round jar in a dark room throws on a sheet of cardboard held over it patterns of conic sections, which pass into each other as you change the position of the cardboard. Children very early learn to love watching figures thrown in light; and there is no age at which this amusement can hurt them, provided that the motion is slow, and that no one excites them by trying to explain things" [11, p. 905].
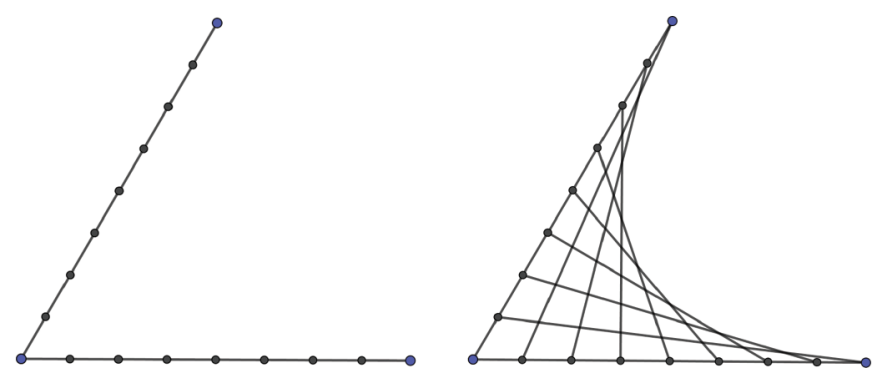

Figure 6. An example of curve stitching.

A long-lasting pedagogical invention of Mary was the curve stitching method; it consists of using cards with small holes placed in specific patterns (for instance, regularly placed on the two sides of an angle as in Figure 6, left). Children would be instructed to string thread in long stitches as in Figure 6, right. Firstly, they can observe that straight lines appear naturally when the thread is tight. Secondly, from certain hole patterns a curve (the envelope of its strung tangents) emerges. There are patterns yielding curves of pursuit, parabolas, deltoids, cardioids, alone and in combinations that children are supposed to discover on their own. The process facilitates their grasp of geometrical patterns.

The importance of critical, independent thinking is emphasized in much of her writing. "For among all the habits which science requires us to form, none is more important than the habit of learning when there is no man to teach us, of profiting by our own past errors, of rising on stepping-stones of our mistaken selves to correcter judgments" [11, p. 898].

Mary followed her own advice to the very end and went wherever her mind took her, never afraid of going against what was accepted or approved by society. Her collected works comprise about fifteen hundred pages written in 


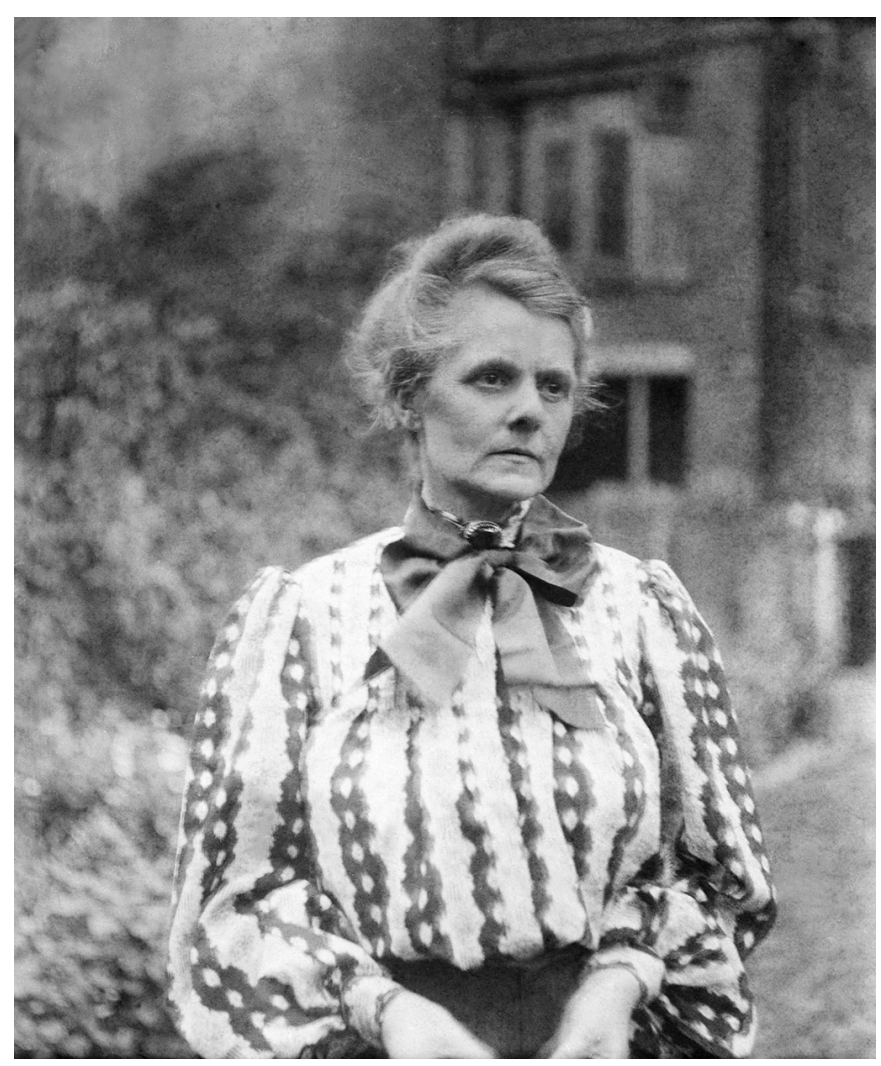

Figure 7. Portrait photograph of Alicia Boole Stott.

small font. It was hard for a topic to escape her pen: besides science and mathematics education, she wrote about child raising, logic, voting rights, theosophy, Judaism, anti-Semitism, Indian mysticism, spirituality, animal rights, vegetarianism, the occult, homeopathy.... She made it her mission to disseminate George's work by adding to it occasional touches of psychology and mysticism, some of which may seem far-fetched to us.

\section{Alicia Enters a Four-Dimensional Space}

Most of the existing information about Alicia (or Alice, as the family called her) comes from H. S. M. Coxeter, with whom she established a close friendship and collaboration in the last decades of her life. (In Mary's extensive Collected Works [11] there is only one brief mention of her daughters.) Coxeter tells us that the whole family lived in a very small, uncomfortable house in London [13, p. 220]. The five girls had to share a grim room; privacy and sunlight were luxuries they could not afford. He also recalls a telling fact about Mary's mothering: to have music in the house she sold George's Royal Society gold medal and bought a harmonium.

Alicia's geometric background consisted of the first two books of Euclid [15, p. 261]. One can conjecture that Mary taught her daughters mathematics, helping them discover axioms and develop theorems naturally, guiding them with questions, aided by thread and cardboard and other materials she used to make ideas tangible.

According to Coxeter, "Mrs Boole's friendship with James Hinton (...) brought to the house a continual stream of cranks. In their one sitting room, they talked endlessly about subjects that Alice, Lucy and Ethel were too young to understand but not too young to brood over" [13, p. 220].

One mathematical crank from the continual stream, Charles, son of James Hinton, brought to the small sitting room of the Booles an excruciatingly intricate system of squares and cubes he had created to get a better grasp of "the fourth dimension." His reasons for the pursuit of this understanding included mysticism, a desire for absolute knowledge, and the belief that humans live in a four-dimensional space they could eventually perceive. The cubes were divided into two sets. Each of the eighty-one cubes of one set had its own Latin name (in Figure 8, right, one cube of this set is shown, with the name of its components). The other set contained twelve cubes, each of them distinctively multicolored (Figure 8, left). Names and colors were relevant to the understanding of "the fourth dimension" and had to be memorized. There were various prescribed ways to arrange the cubes. One of these ways represented the four-dimensional cube or, as Charles christened it, the tesseract.

Charles explained the system to the three younger Boole sisters. Alicia, the only one who followed his explanations, kept pursuing the understanding of these ideas. She was between sixteen and eighteen years old, about the same age her father was when he focused the bulk of his intellectual efforts on math [13, p. 221]. (Hinton's cubes outlived their creator, but Alicia seems to have been one of the few, if not the only one, to master them. Many tried, some with dire consequences, as described in the addendum of one of Martin Gardner's columns for the Scientific American [12, p. 52].)

The story then becomes as colorful as the cubes. In 1880 Charles married the oldest of the Boole sisters, Mary Ellen. Three years later and under a false name, he
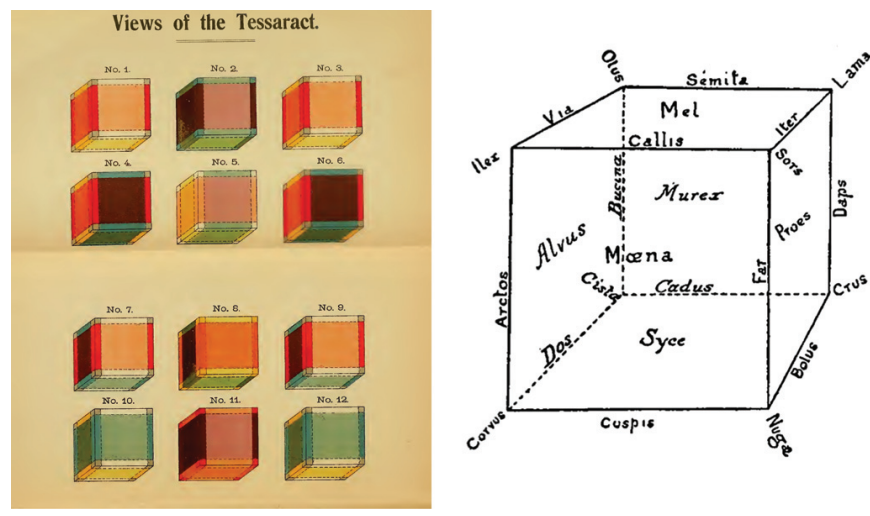

Figure 8. Hinton cubes as they appeared in his book The Fourth Dimension, left. On the right, a cube with the names of its components, from A New Era of Thought [14]. 
married another woman. Edward Thring, the headmaster at Uppingham, where Hinton worked, wrote in his diary, "What a piteous and strange thing, Hinton came in with his wife and his sister (I understand) to say he had committed bigamy and that they had persuaded him to give himself up to justice." The scandal, picked up by many London newspapers, became the talk of the town. Hinton and his "first" family (Mary Ellen and four young children) moved to Japan.

In the 1880 s Alicia and H. John Falk, a lawyer and amateur mathematician, worked on the edition of a manuscript written by Charles Hinton, A New Era of Thought [14]. The book was published in 1888; its preface states: "The MSS which formed the basis of this book were committed to us by the author, on his leaving England for a distant appointment" [14, p. iii]. (Jorge Luis Borges wonders in the prologue to an anthology of Hinton's stories whether this last sentence insinuates a suicide or an escape of "our fugitive friend" to that fourth dimension he had managed to glimpse with obstinate discipline.) The preface continues, "It was his wish that we should construct upon them a much more complete treatise than we have effected, and with that intention he asked us to make any changes or additions we thought desirable." One of these additions was "Appendix H: Sections of the Tessaract."

\section{Regular Polytopes in All Dimensions}

By the end of the nineteenth century, the time was ripe for the study of higher-dimensional objects. Riemann's "Habilitationsschrift" lecture, published in 1867, had introduced the idea of manifolds of any dimension [19, p. 133]. The regular four-dimensional polytopes were first described by the Swiss mathematician Ludwig Schläfli in a manuscript he had produced by 1852; this work was rejected by the Akademie in Vienna for its length and was not published until 1901, six years after his death. Several mathematicians, unaware of Schläfli's work, discovered the regular polytopes on their own [10, p. 194]. Alicia was one of them.

Regular convex polytopes are the four-dimensional analogues of the two-dimensional regular polygons and the three-dimensional Platonic solids. Following Coxeter [10, p. 128], one defines an n-dimensional polytope as a convex, bounded region of Euclidean $n$-dimensional space, enclosed by finitely many hyperplanes. A cell of a polytope $P$ is the intersection of $P$ with one of the bounding hyperplanes. An $n$-dimensional polytope $P$ is regular if $n=2$ and $P$ is a regular polygon or if $n>2$ and its cells are regular $(n-1)$ dimensional polytopes, also regular at each vertex $(V$ is a regular vertex if the midpoints of all edges emanating from $V$ lie in one hyperplane, and these midpoints are themselves the vertices of a regular $(n-1)$-polytope).

There are infinitely many regular polytopes in dimension two and exactly five of them in dimension three (the tetrahedron, the octahedron, the icosahedron, the cube, and the dodecahedron). Three types of polytopes exist in all dimensions $n$ larger than three: the $(n+1)$-cell or $n$-simplex, the $2 n$-cell or $n$-cube, and the $2^{n}$-cell or orthoplex (note that $n+1,2 n$, and $2^{n}$ are the numbers of cells of each polytope). The cells of the first and last are ( $n-$ $1)$-simplices; the cells of the second are $(n-1)$-cubes. If $n \geq 5$, those three are all the regular polytopes; in dimension four there are exactly three more: the 24-cell, the 120-cell, and the 600-cell, whose cells are octahedra, dodecahedra, and tetrahedra, respectively.

A section of a polytope $P$ is the intersection of $P$ with a hyperplane. (A $k$-principal section is one where the hyperplane is perpendicular to the line through the center of $P$ and the center of a $k$-dimensional face of $P$. For instance, in a four-dimensional polytope, 3-principal sections are determined by hyperplanes perpendicular to a line from the center of $P$ to the center of one of the three-dimensional Platonic solids bounding $P$.)
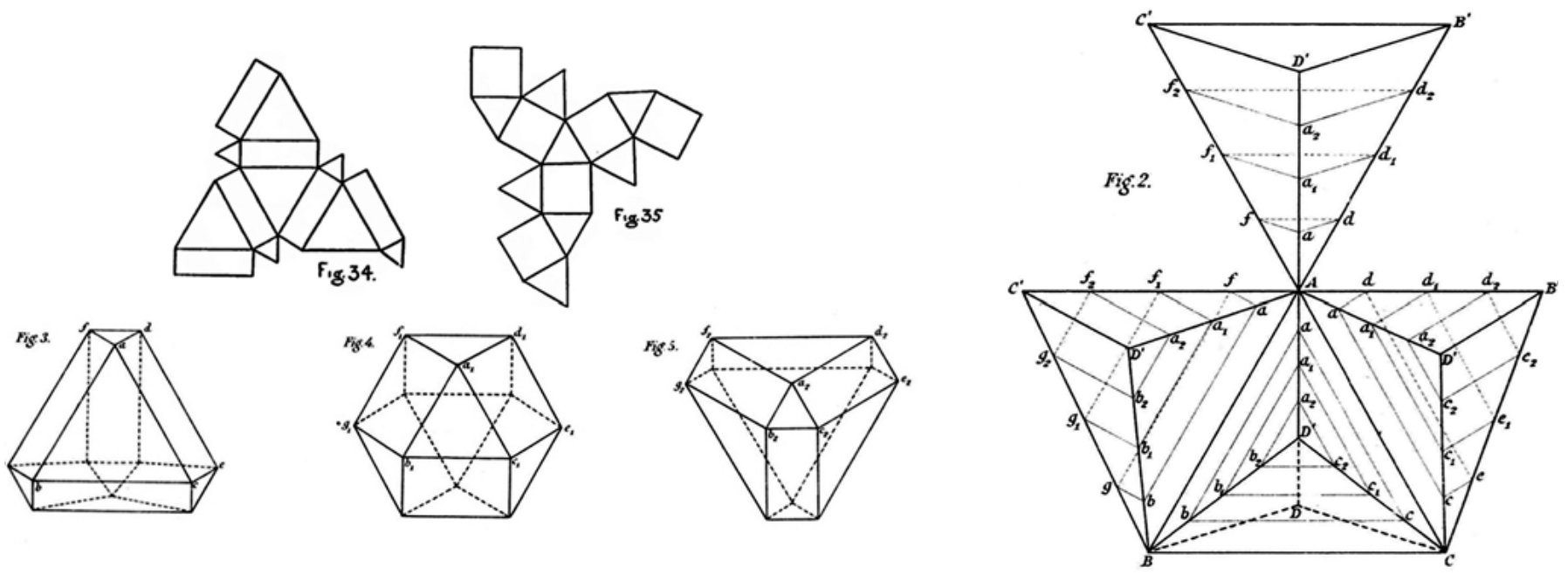

Figure 9. 3-principal sections of the 16-cell. Illustrations from A New Era of Thought [14] (left top). Illustrations from Alicia Boole Stott's paper [9] (right and left bottom). 


\section{Alicia Brings Models from the Four-Dimensional Space}

An open question is how Alicia went from playing with Hinton's cubes as a teenager to her deep understanding of the regular polytopes in four dimensions. We propose here the following hypothesis: her work on A New Era of Thought is the missing link. The appendix she wrote with Falk (although all evidence suggests that it is solely her work) discusses sections of three of the regular four-dimensional polytopes: the four-dimensional cube (rebaptized tessaract in this text), the 16-cell (referred to as tetra-tessaract), and the 24-cell (referred to as octa-tessaract). Alicia seems to have coined the words "tetra-tessaract" and "octa-tessaract" after rediscovering these objects.

The Appendix H of [14, p. 216] reads, "A few figures are given, which, if cut out and folded along the lines, will show some of the sections of a tessaract. But the reader is earnestly begged not to be content with looking at the shapes only. That will teach him nothing about a tessaract, or four-dimensional space, and will only tend to produce in his mind a feeling that 'the fourth dimension' is an unknown and unthinkable region, in which any shapes may be right, as given sections of its figures, and of which any statement may be true. While, in fact, if it is the case that the laws of spaces of two and three dimensions may, with truth, be carried on into space of four dimensions; then the little our solidity (like the flatness of a plane-being) will allow us to learn of these shapes and relations, is no more a matter of doubt to us than what we learn of two- and three-dimensional shapes and relations."

The figures (almost certainly drawn by her) of the sections of the tesseract illustrating the Appendix H of [14] are the natural ancestors of those in her paper [9]. For instance, the 3-principal sections of the 24-cell are in Figure 9: on the left top from [14], and on the right and left bottom we see the corresponding figures from [9].

The Appendix $\mathrm{H}$ describes the four principal sections of a regular four-dimensional polytope in the following way: "It is clear that there are four orders of sections of every four-dimensional figure; namely, those beginning with a solid, those beginning with a plane, those beginning with a line, and those beginning with a point."

The explanations of the Appendix are their best when the complicated Latin names Hinton gave to each point, segment, cube, and four-dimensional cube are not used.

During the 1880s Alicia was living alone near Liverpool and doing secretarial work for Falk, with whom she had coedited Hinton's book [13]. Walter Stott, an actuary, joined Alicia and Falk's team to work on a new edition of George's Laws of Thought. Alicia married Walter in 1891, and very soon the couple had two children, Mary and Leonard.

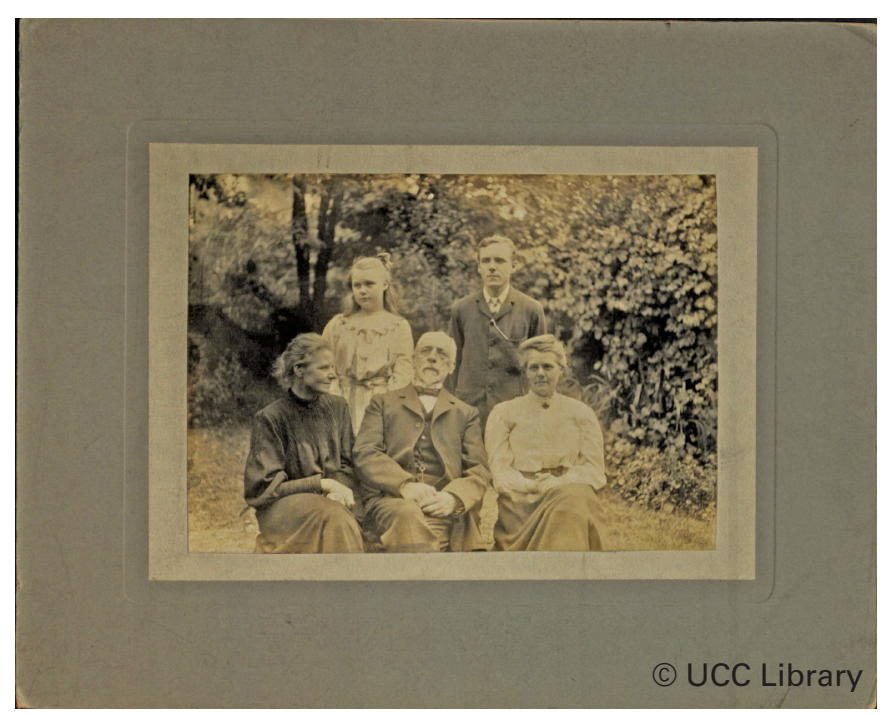

Figure 10. BP/1/363 Monochrome photograph taken outdoors of Professor Schoute; Alice Stott and her daughter, Mary; MargaretTaylor and her son, Geoffrey.
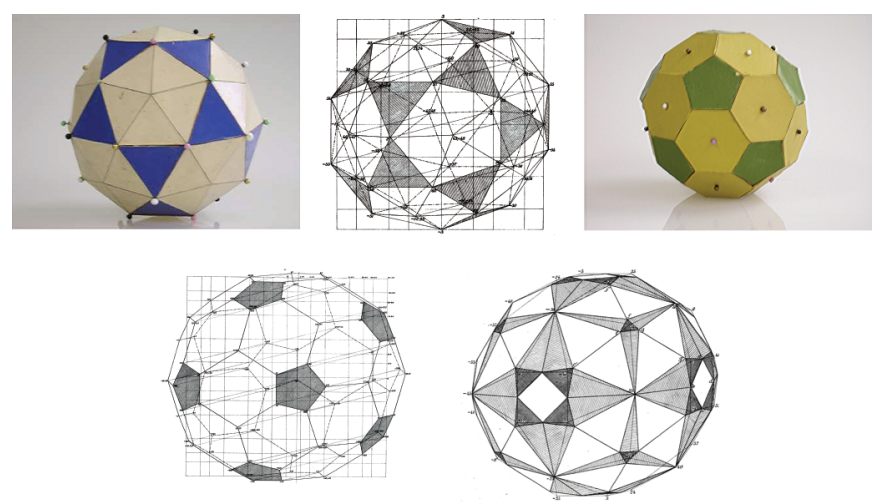

Figure 11. Representation of central sections of polytopes. The two models were made by Alicia Boole and the three drawings by Schoute. The first and second correspond to the central 0 -principal section of the 600 -cell, the second and third to the central 3-principal section of the 120-cell, and the fifth to the 3-principal section of the 600-cell. Compare this section to the central drawings in each row of Figure 12.

\section{The Meeting of the Visual and Analytical Minds}

Meanwhile, across the sea, the Dutch mathematician Pieter Schoute was computing central sections of four-dimensional polytopes (central sections are those determined by a hyperplane passing through the center of the polytope). Possibly because of his interest in math-evidenced by the fact that he worked on editing George's work-Walter learned about Schoute's published work. When he told Alicia about it, she wrote to Schoute that she had arrived at the same results as his by very different methods. Figure 11 illustrates one more instance of the simultaneous sprouting of the same mathematical ideas in two minds with no direct contact. In fact, she had computed all the principal sections of the regular four-dimensional polytopes. Clearly, after the publication of A New Era of Thought she continued with her 


\section{HISTORY}
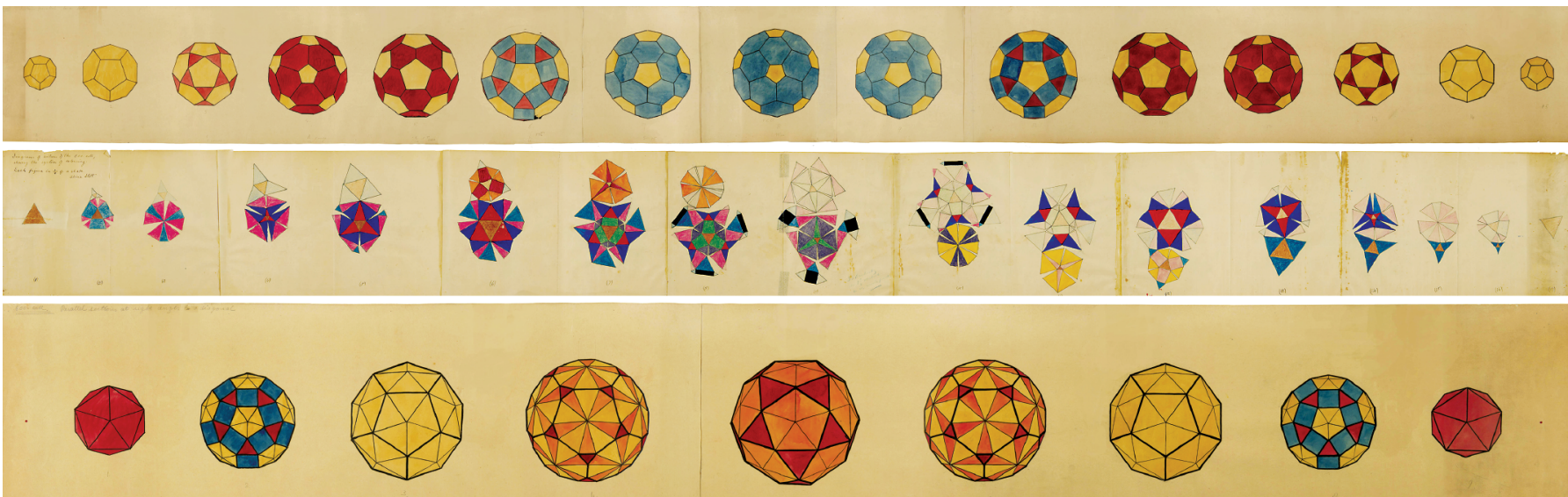

Figure 12. Alicia's drawings of 0-principal sections of the 120-cell (top), and 0- and 3-principal sections of the 600-cell (middle and bottom, respectively). The drawings are used with permission of the Special Collections Department of Groningen University Library (HS Add 394). The photographs of the drawings were taken by Dirk Fennema.

exploration of four-dimensional geometry, rediscovering the three regular polytopes that had not appeared in the Appendix, as well as studying and making cardboard models of the principal sections of all of them. Coxeter writes that Alicia sent Schoute photographs of a series of parallel sections of her models [13, p. 222].

Schoute answered enthusiastically, proposing a collaboration. Alicia and Schoute spent many summer holidays working together in England and published their results in a joint paper [9]. The photograph in Figure 10 was taken during one of those summers. Coxeter commented, "Mrs. Stott's power of geometrical visualization supplemented Schoute's more orthodox methods, so they were an ideal team." Schoute also arranged for Alicia to publish her results. These papers, as well as the models (Figure 12) and drawings (Figure 9) she shared with Schoute, reflect her deep visual understanding of geometry.

Alicia's first published paper [8] describes the principal sections of the six regular four-dimensional polytopes, determined by a hyperplane perpendicular to the line from the center of the polytope to the center of one of its cells.

Consider, for example, the 16-cell $S$, one of its bounding cells $C$ (a tetrahedron), and the 3 -sections of $S$, that is, the sections determined by hyperplanes parallel to the one that contains $C$. In order to visualize these sections, Alicia "puts" one tetrahedron in each of the four faces of $C$, one in each of its six edges, and one in each of its four vertices. Thus there are in total fifteen tetrahedra. After identifying the pairs of appropriate faces (which includes all pairs of faces that share an edge), four faces remain free. By attaching a last tetrahedron to these four faces, the 16-cell is complete.

To find the sections one needs to "slide" the appropriate hyperplane across these layers. The "first" section, given by the hyperplane containing the first cell, is, of course, a tetrahedron. When the hyperplane moves slightly further away, the edges of the tetrahedron become thin rectangles and the vertices, small triangles; see Figure 9, bottom left. As the hyperplane keeps moving, the rectangles become squares and all the triangles become congruent. Then the process is reversed: the squares become rectangles (and the former longer pair of long sides becomes the shorter), and the triangles that were smaller become larger, until the hyperplane intersects the "last" tetrahedron, which contains the last attached cell. These sections are depicted in Figure 9 , bottom left. On the right, a few of the tetrahedra sharing a vertex are shown (rotated so that all are in the first hyperplane), as well as the successive intersections with the hyperplane.

In 1914, a few months after Schoute's death, Alicia received an honorary doctorate from Groningen, Schoute's university. Her comment when receiving the document in a cardboard cylinder was: "This will be a good place to keep sticks of macaroni!" [13, p. 223].

\section{AuntAlice Goes toTea}

There is no evidence of Alicia's mathematical activity in the years after Schoute's death in 1913. But in 1928, Geoffrey Ingram Taylor (the son of Alicia's sister Margaret and a remarkable mathematician and physicist) introduced Alicia to the geometer H. S. M. Coxeter, who was then a PhD student at Cambridge. As mentioned above, a stimulating, warm friendship grew between the geometer, then in his early twenties, and the almost seventy-year-old Aunt Alice, as Coxeter affectionately called her.

Coxeter's advisor, Henry F. Baker, established Saturday afternoon research seminars called "tea parties." Coxeter and Aunt Alice gave one of the lectures with the help of her sections of polytopes [20, p. 72].

Aunt Alice wrote to Coxeter in 1935, "I can't tell you how thrilled I am at the thought of seeing your magic mirrors. It seems too wonderful for words and I am longing for next 


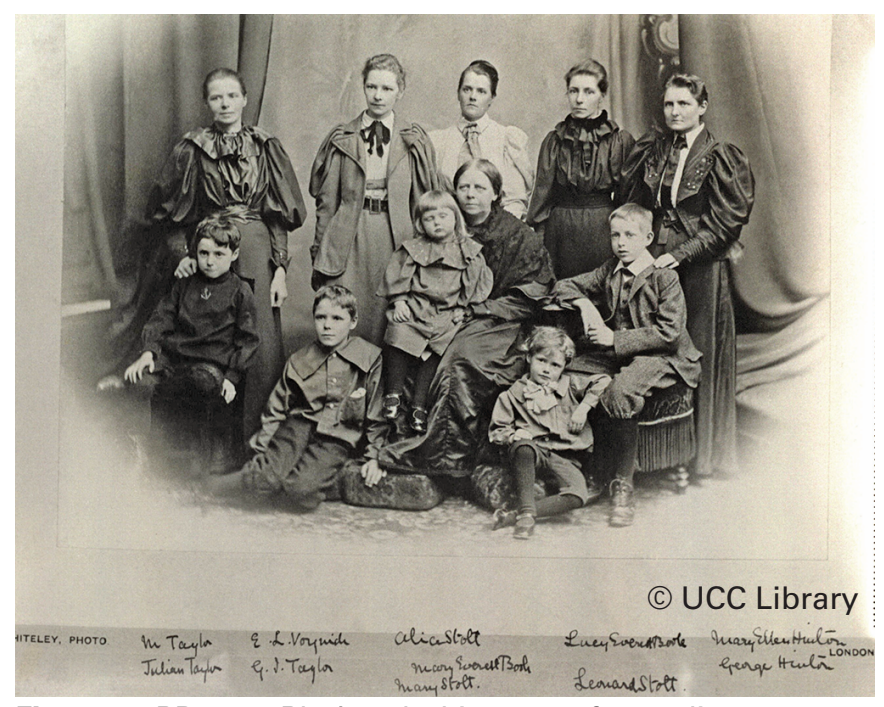

Figure 13. BP/1/362 Black and white copy of an earlier photograph of the Boole family showing Mary Boole, her five daughters and grandchildren, Julian and Geoffrey Taylor, Mary Leonard Stott, and George Hinton, grouped in a studio portrait. Names annotated.

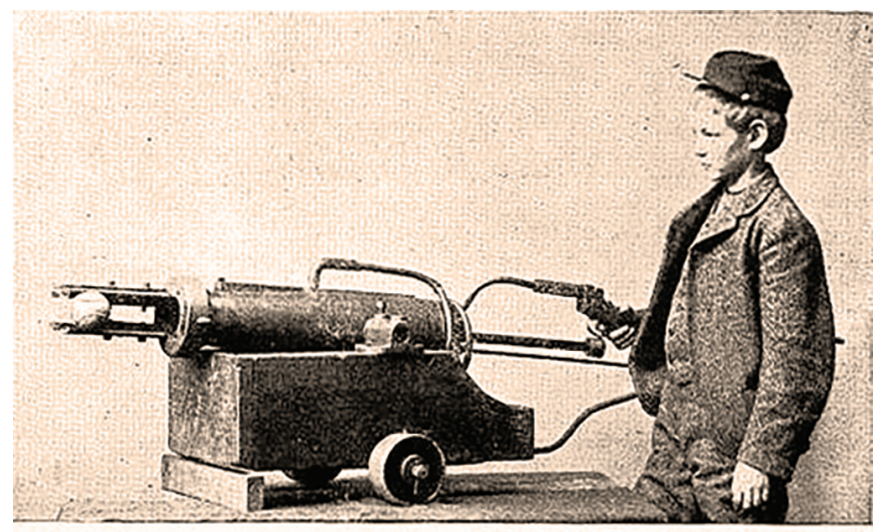

MECIIANiCal, PITCHER-EXPERIMENTAL, FOMM.

Figure 14. Hinton Pitching Machine. Illustration from an article written by Hinton in Harper's Magazine in 1897.

week to come. How you will wake up the stuffy mathematicians on Saturday!!" [20, p. 79].

Coxeter moved to Toronto in 1936. In her good-bye letter, Aunt Alice wrote, "While I have been writing, my mind has gone back to the lovely world we have visited together, and which you have made so much your own. I wonder where you will get to in it! How I wish I could follow" [20, p. 116].

\section{The Boole Genes}

The achievements of the descendants of Mary and George Boole can fill many, many pages. Some of them are listed below.

Each of the five Boole sisters-Mary Ellen, Margaret, Alice, Lucy, and Ethel-shined with a special, personal, unique light.
Mary Ellen, the eldest, wrote a book of poems and gave lectures about modern poetry. A year after the sudden death of her husband, Charles Hinton, she committed suicide. Sometime before she had written, "Life is something that we have the privilege of ending when we choose. When life becomes a burden it is everybody's right to exercise that privilege." Hinton himself, after spending a few years in Japan, traveled to the US in 1893, where he worked for a few years as instructor of mathematics at Princeton University. There, he invented a baseball pitching machine that threw balls to batters (Figure 14). The invention made more noise than success. After a few jobs, he ended up working at the Patent Office in Washington. During his life, Hinton published quite a few obscure and attractive texts, including several "mathematical romances." One of his obituaries, in the Courier-News (Bridgewater, New Jersey) datelined Washington, May 3, 1907, read, "One of the most erratic geniuses who ever graduated from Oxford and then came to the university life in this country, Charles Howard Hinton, second assistant examiner of the United States Patent Office, has just died in this city." After his death, Hinton and his ideas appeared in many academic and fictional works.

Margaret studied painting and mothered Geoffrey Ingram Taylor.

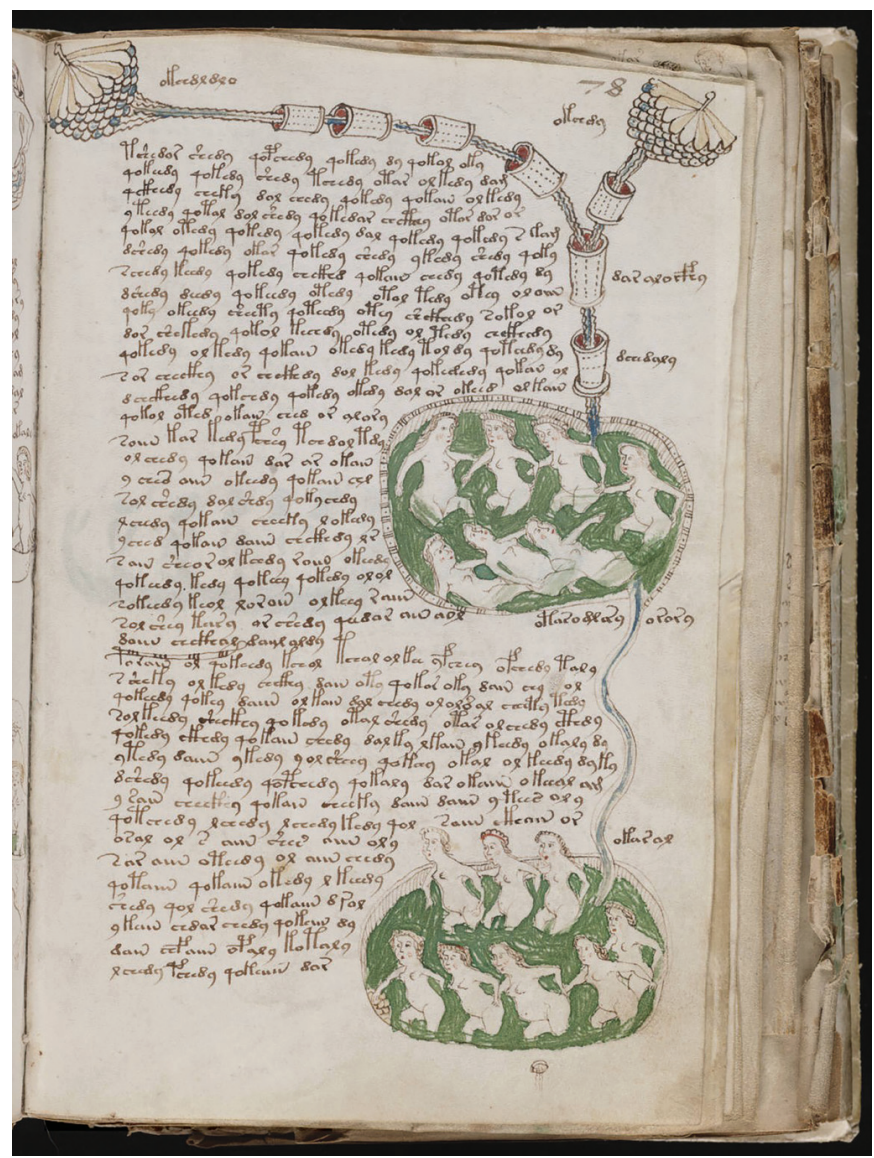

Figure 15. A page of the mysterious Voynich manuscript. 


\section{HISTORY}

Lucy Everest Boole was a Lecturer in chemistry at the London School of Medicine for Women and the first woman elected a Fellow of the Institute of Chemistry. She was the first female coauthor to have a paper read before the London Pharmaceutical Society. She died at the age of forty-two [15, p. 265].

The youngest Boole sister, Ethel, influenced by readings about the conditions of the suffering of the Russian people under tsarist rule, travelled to see it for herself. She became an activist, visited prisons, smuggled propaganda, and brought medical aid to isolated peasants. She also composed music and wrote four novels. The first of these, The Gadfly, was an immediate international success and was made into a film in the Soviet Union with music by Dmitri Shostakovich. She married the Polish exile Wilfrid Voynich, who shared her revolutionary ideas and was one of the world's greatest experts on, and dealers in, rare books. At the beginning of the 1900s, Voynich bought at the Villa Mondragone in Italy a book (Figure 15 shows one of its pages) from medieval times, written in a language that no one has ever been able to decipher, the pages filled with text and strange creatures and plants interwoven in a dreamlike fashion. For some time it was believed the book was a hoax, but this hypothesis has been discarded thanks to carbon

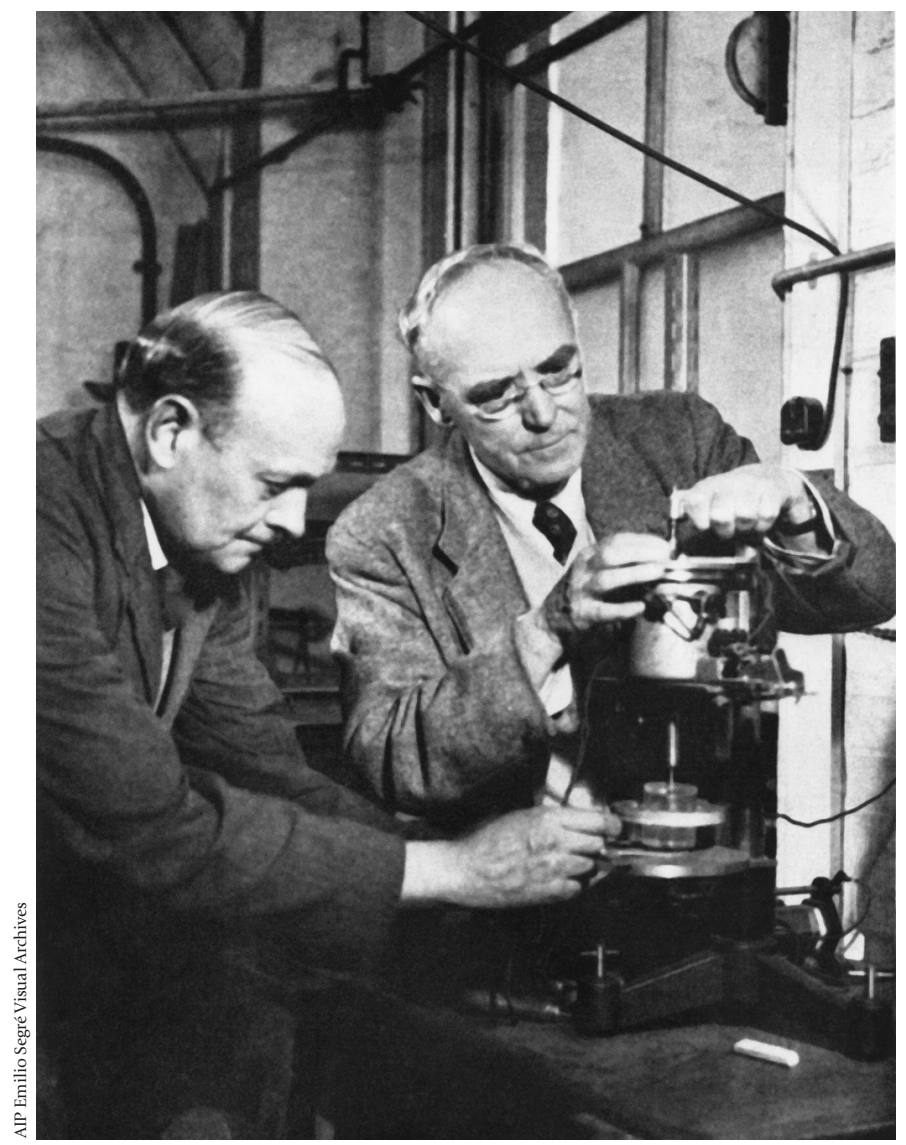

Figure 16. Geoffrey Ingram Taylor (right) at age 69, in his laboratory with his assistant, Walter Thompson. dating and studies of language patterns. Many have tried to decipher it; the hypotheses about its content vary from stating it is a treatise on nature, written in a Near Eastern or Asian language, to interpreting it as a scientific diary written by Roger Bacon with a substitution cipher. No hypothesis has held up, and the search for the meaning of the Voynich manuscript, as it is known, continues.

As mentioned before, among George and Mary's grandchildren was the renowned scientist Geoffrey Ingram Taylor. He approached problems in applied mathematics, classical physics, and engineering science from a fresh point of view. Geoffrey was proud of his grandfather George and the amateur passion for mathematics of his Aunt Alice; he seemed to like to see himself as maintaining this family tradition [1, p. 5]. He was accessible and friendly, always ready to answer a question of a young scientist. Geoffrey was knighted in 1944 and appointed to the Order of Merit in 1969 [1, p. xv]. He also won the gold medal from the Royal Society, the "same" gold medal, as John Lienhard suggested, that his grandmother had once sold or, as Lienhard wrote, reinvested.

Leonard Boole, Alicia's son, invented a portable X-ray machine, an artificial pneumothorax apparatus, and a system of navigation based on spherical geometry. He was also a medical doctor, a pioneer in the treatment of tuberculosis [15, p. 264].

Documents from the Patent Office from the 1920s attribute the invention of the Jungle Gym to another of George and Mary's grandchildren: the lawyer Sebastian Hinton, one of the four sons of Charles and Mary Ellen. During their childhood in Japan, Charles had made in their backyard a multiple-cube bamboo framework so his children could get a better grasp of the three dimensions of the world we live in and eventually visualize a four-dimensional space. Sebastian married Carmelita Chase, who would later found the Putney School, a renowned progressive boarding school in Vermont; at some point, Coxeter was invited there and seriously contemplated staying.

Among George and Mary's great-grandchildren one can find Howard Everest Hinton, a distinguished entomologist; William Hinton, a Marxist writer; and Joan Hinton. Joan was a nuclear physicist and one of the few women scientists involved in the Manhattan Project in Los Alamos. She worked on the development of the first atomic bomb in Los Alamos and was one of the few eyewitnesses of the first atomic explosion. The devastating consequences of the bombing of Hiroshima converted her into an outspoken pacifist. In 1948 she gave up physics and went to live in Maoist China. She remained a strong believer in the Maoist cause until her death in 2010.

Two great-great-grandchildren are worthy of mention: Carma Hinton, who made award-winning documentaries, and Geoffrey Everest Hinton, who won the 2018 Turing Award for his pioneering work in Artificial Intelligence. 


\section{Epilogue}

The story of the Boole family is one of original talent and persistence. It illustrates how important it is to keep one's mind open to new ideas, even when these ideas come from unexpected sources. One wonders how much mathematical talent is lost because of nonmathematical barriers like gender or social status.

The probability that George Boole's early academic work might have been overlooked is far from small, as it is that he might never have obtained an academic position. Pieter Schoute could easily have never bothered to answer Alicia's first letter. H. S. M. Coxeter might never have exchanged ideas with Alicia or, later, might never have written about her. Despite or because of the laws of probability, as modeled by George, all of these unfortunate events that could have easily taken place never happened, and, fortunately, intellectual contributions of the Booles are now part of our world.

ACKNOWLEDGMENTS. The author is indebted to Tony Phillips, who introduced the author to Alicia Boole through his column [18]. Tony Phillips, Noor Kamal, Nissim Ranade, Chandrika Sadanand, Dennis Sullivan, and the referee gave suggestions that greatly improved this work.

Erica Flapan deserves gratitude for suggesting the topic and Della Dumbaugh for her infinite patience as an editor.

Thanks for providing material and information are due to Jamie Carstairs from the Special Collections of University of Bristol Libraries; to Jan van Maanen and Henk de Snoo from the University of Groningen; to Irene Polo-Blanco from the Universidad de Cantabria; to Emma Horgan, Maureen Fitzgerald, Emer Twomey, and Cronan O Doibhlin from UCC Library, University College Cork; to John H. Lienhard from the University of Houston; and to Fred Drissen, managing editor, NAWhere.

\section{References}

[1] Batchelor G, The Life and Legacy of G. I. Taylor, Cambridge University Press, Cambridge, 1996. MR1447190

[2] Boole G, Exposition of a general theory of linear transformations, Parts I and II, Cambridge Math. J. 3 (1842), 1-20, 106-119.

[3] Boole G, On a general method in analysis, Philosophical Transactions of the Royal Society of London 134 (1844), 225282.

[4] Boole G, The Mathematical Analysis of Logic, Being an Essay Towards a Calculus of Deductive Reasoning, Philosophical Library, New York, NY, 1948. MR0028250

[5] Boole G, An Investigation of the Laws of Thought, on Which Are Founded the Mathematical Theories of Logic and Probabilities, Dover Publications, Inc., New York, 1957, MR0085180
[6] Boole G, A Treatise on Differential Equations, 5th ed., Chelsea Publishing Company, New York, 1959. MR0107033

[7] Boole G, A Treatise on the Calculus of Finite Differences, reprint of the 1860 original, Cambridge Library Collection, Cambridge University Press, Cambridge, 2009. MR2850060

[8] Boole Stott A, On certain series of sections of the regular four-dimensional hypersolids, Verhandelingen der Koninklijke Akademie van Wetenschappen te Amsterdam 7 (1900), no. 3, 1-21.

[9] Boole Stott A, Schoute PH, On the sections of a block of eightcells by a space rotating about a plane, Verhandelingen der Koninklijke Akademie van Wetenschappen te Amsterdam 9 (1908), no. 7, 3-25.

[10] Coxeter HSM, Regular Polytopes, Methuen \& Co., Ltd., London; Pitman Publishing Corporation, New York, 1948; 1949. MR0027148

[11] Everest Boole M, Collected Works, edited by E. M. Cobham, London: The CW Daniel Company, 1931.

[12] Gardner M, Mathematical Carnival, second ed., with a foreword by Conway J, Mathematical Association of America, Washington, DC, 1989. MR1007833

[13] Grinstein LS, Campbell PJ (eds.), Women of Mathematics, a Biobibliographic Sourcebook, Greenwood Press, Westport, CT, 1987. MR911481

[14] Howard Hinton C, A New Era of Thought, S. Sonnenschein \& Company, 1888.

[15] MacHale D, The Life and Work of George Boole: A Prelude to the Digital Age, Cork University Press, 2014.

[16] Michalowicz KDA, Mary Everest Boole (1832-1916): An Erstwhile Pedagogist for Contemporary Times, Vita mathematica (Toronto, ON, 1992; Quebec City, PQ, 1992), MAA Notes, vol. 40, Math. Assoc. America, Washington, DC, 1996, pp. 291-299. MR1391749

[17] Nahin PJ, The Logician and the Engineer: How George Boole and Claude Shannon Created the Information Age, Princeton University Press, Princeton, NJ, 2013. MR2954056

[18] Phillips T, The Princess of Polytopia: Alicia Boole Stott and the 120-cell, American Mathematical Soc. Feature Column, 2006, https: //www. ams . org/fcarc-boole.

[19] Polo-Blanco I, Theory and history of geometric models, PhD thesis, University of Groningen, 2007.

[20] Roberts S, King of Infinite Space: Donald Coxeter, the Man Who Saved Geometry, with a foreword by Hofstadter DR, Walker and Company, New York, 2006. MR2352131

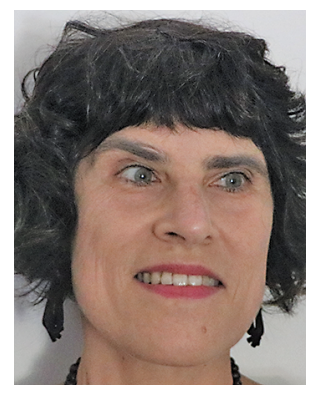

Moira Chas

\section{Credits}

Figures 1, 2, 3, 4, 10, and 13 are used by permission of The Papers of George Boole, F.R.S., ${ }^{\circ}$ UCC Library, University College Cork, Ireland.

Figure 5 is from Mary Everest Boole Collected Works, 1931. 


\section{HISTORY}

Figure 6 is courtesy of the author.

Figure 7 is used with the permission of the University of Bristol Library, Special Collections (DM1718/A.98, Howard Everest Hinton Archive).

Figure 8 (left) is from Hinton's book, The Fourth Dimension, 1912.

Figure 8 (right) and Figure 9 (left) are from Hinton's book, A New Era of Thought, 1888.

Figure 9 (right) is from Alicia Boole's article, 1900.

Figure 11 photographs belong to the University Museum at the University of Groningen. Used with permission.

Figure 11 drawings are from Pieter Schoute's paper, 1894.

Figure 12 drawings are used with permission of the Special Collections Department of Groningen University Library (HS Add 394). The photographs of the drawings were taken by Dirk Fennema.

Figures 14 and 15 are public domain, via Wikimedia Commons.

Figure 16 is courtesy of AIP Emilio Segré Visual Archives.

Author photo is by Clara Sullivan.

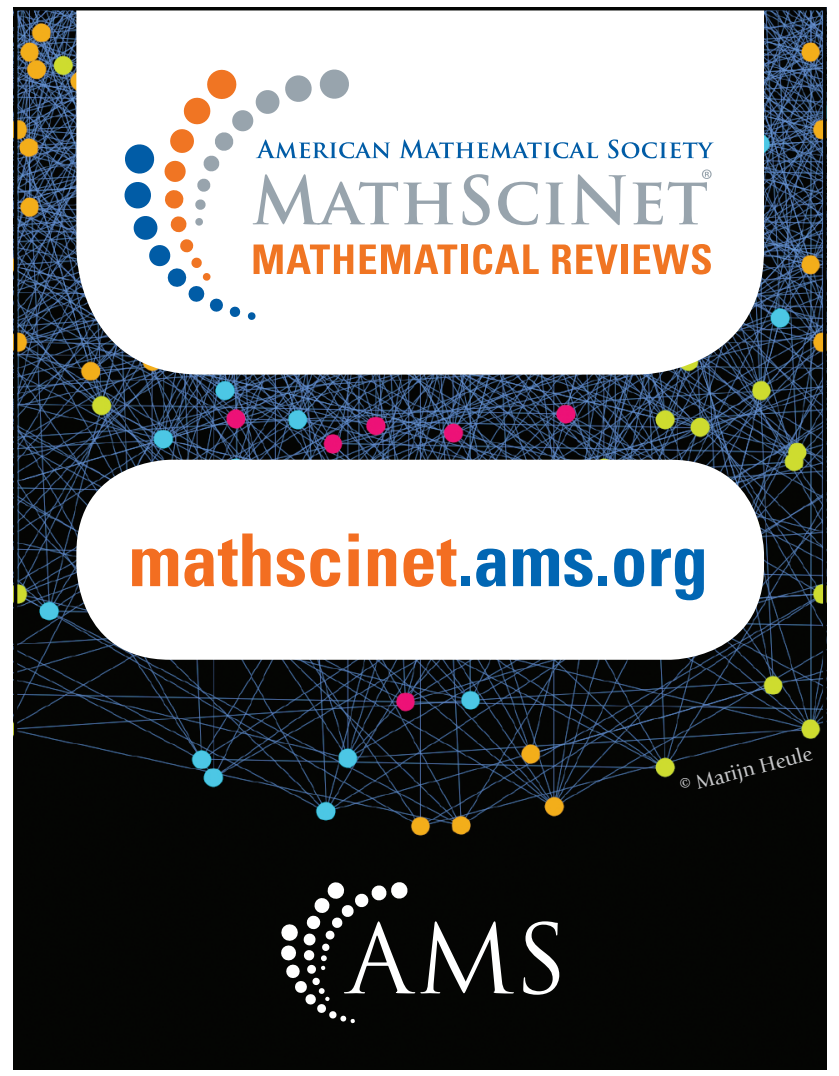

\section{GET MORE FROM YOUR JOURNALS}

Learn about AMS MathViewer:

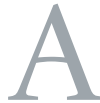

$\mathrm{n}$ interactive, dual-panel reading experience for journals published by the American Mathematical Society.

AMS MathViewer's responsive HTML format perfectly renders mathematical content on desktop, tablet, or phone. Click on embedded links to formulas, theorems, figures, and references to view them in the second panel, in tandem with the original text.
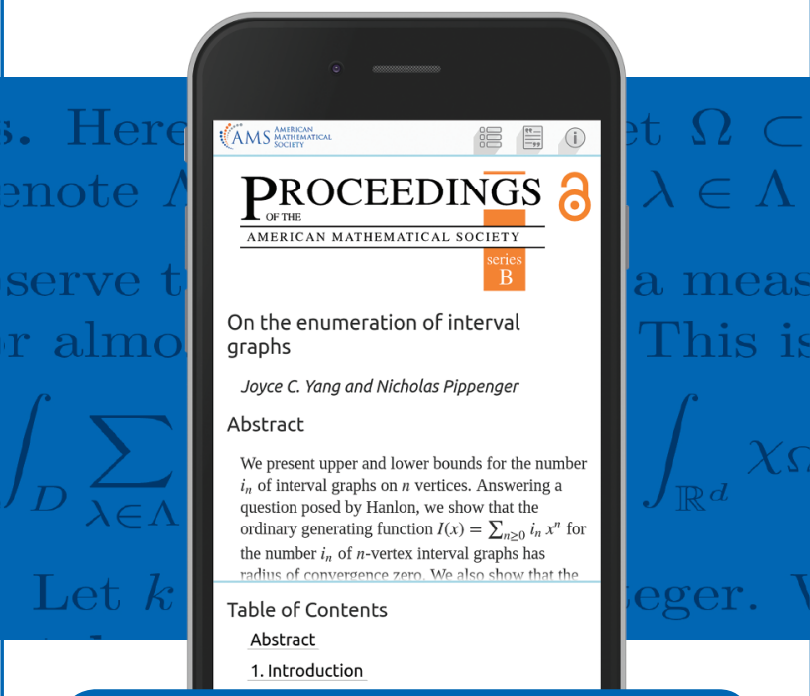

CURRENTLY AVAILABLE FOR:

Transactions of the AMS - Series B

Proceedings of the AMS - Series B

Journal of the American Mathematical Society

Mathematics of Computation

(Starting with 2019 volumes and

select articles from past issues.)

Keep an eye out for additional journals that will become available throughout the year.

www.ams.org/AMSMathViewer

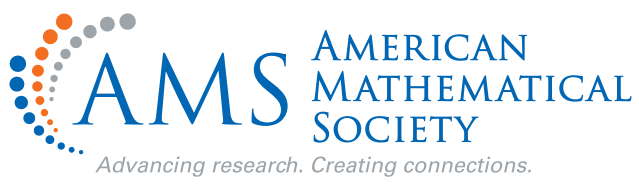

